\title{
The role of family social capital in immigrants' entrepreneurial opportunity creation processes
}

\author{
Quang Evansluong ${ }^{\mathrm{a}}$, Marcela Ramírez Pasillas ${ }^{\mathrm{b}}$
}

${ }^{a}$ Faculty of Business and Law, Bristol Business School, University of the West of England, Bristol, United Kingdom;

${ }^{b}$ CeFEO, Centre for Family Enterprise and Ownership, Jönköping International Business School, Jönköping University, Jönköping, Sweden

\begin{abstract}
This paper conducts an inductive case study to build a theory on the role of family in both the host and home countries in immigrant entrepreneurs' attempts at creating entrepreneurial opportunities. We used the perspectives of the opportunity creation process and family social capital. We relied on data collected from four cases of immigrant entrepreneurs from Lebanon, Syria, Cameroon and Mexico who have established businesses in Sweden. The paper identified three sources of family social capital: family duties, family trust and family support as being relevant for creating opportunities. While family duties triggered the process of forming an entrepreneurial idea, this process was advanced by the existence of family trust. Family support was then the building block for launching an entrepreneurial idea. By identifying these three sources of family social capital we show that families in the host and home countries contribute to immigrant entrepreneurs' opportunity creation in different ways.
\end{abstract}

Keywords: Immigrant entrepreneurship; opportunity creation; family social capital; entrepreneurial ideas; home country; host country, family duty; family trust. 


\section{Introduction}

Over the last few years, there has been increasing attention on entrepreneurial opportunities in general (Ardichvili, Cardozo \& Ray, 2003; Zahra, 2008; Korsgaard 2011; Suddaby, Brutton \& Si, 2015) and immigrant entrepreneurship in particular (Ram, Theodorakopoulos \& Jones, 2008; Jones, Ram, Edwards, Kiselinchev \& Muchenje, 2012; Bolívar-Cruz, Batista-Canino \& Hormiga, 2014).

An entrepreneurial opportunity is a key attribute of entrepreneurship research (Fletcher, 2006; Alvarez \& Barney, 2007, 2010; Randerson, Degeorge \& Fayolle, 2016) because it is a critical step in establishing a new venture (Hills, Lumpkin \& Singh, 1997; Gartner, Carter, \& Hills, 2003; Vogel, 2016).

Developing entrepreneurial opportunities implies that immigrant entrepreneurs rely on networks and resources in two contexts - the host and home countries -- to generate entrepreneurial ideas (Bagwell, 2008; Kloosterman, 2010; Bolívar-Cruz, Batista-Canino \& Hormiga, 2014). Research calls for a further understanding of "why, how and when do individuals and/or organizations pursue new ventures, while relying on abilities and opportunities stemming from the exploitation of resources, both social and economic, in more than one country?' (Drori, Honig \& Wright, 2009: 1002).

One particular dimension that may link networks and resources in the host and home countries while creating an entrepreneurial opportunity is the family. While general literature on entrepreneurial opportunities identifies the importance of family in creating these opportunities (Aldrich \& Cliff, 2003; Evansluong, 2016), there is scarce literature on the role of the family in the process of creating entrepreneurial opportunities.

Literature on immigrant entrepreneurship and entrepreneurial opportunities acknowledges the family as an important institution and repository of family social capital providing a basis for trust, collective action and resource mobilization (Aldrich and Waldinger, 1990; Ram \& Holliday, 1993; Sanders \& Nee, 1996). Yet, research on immigrant entrepreneurship and entrepreneurial opportunity creation provides a somewhat fragmented and incomplete picture of the role that family social capital plays in creating entrepreneurial opportunities (Jones et al., 2012). Literature on immigrant entrepreneurship does not recognize the specific ways in which family in two contexts -the host and home countries -- matters in creating entrepreneurial opportunities and what the outcomes of such influences are (e.g., Bagwell, 2008; Ram et al., 2008). Dimov 
(2007a: 717) further suggests that the role of the family dimension should be interpreted in a processual manner instead of a 'single, one time insight.'

Consequently, our research question is: What role does family social capital, in both the host and home countries, play in creating entrepreneurial opportunities at different moments of the process?

To address this research question, we conducted an inductive case study to build a theory on the role that family social capital plays in the host and home countries in immigrant entrepreneurs' creating entrepreneurial opportunities. We identified four cases of immigrant entrepreneurs from Lebanon, Syria, Cameroon and Mexico who have established businesses in Sweden. The case study was conducted between 2013 and 2016; the immigrant entrepreneurs were located in Jönköping, Sweden.

We found three sources of family social capital from the host and home countries that played important roles in the process of creating opportunities: family duties, family trust and family support. While literature on immigrant entrepreneurship recognizes family duties that entrepreneurs need to fulfil (e.g., Nee and Sanders, 2001), our findings advance existing literature as our study shows that family duties trigger the process of forming an entrepreneurial idea because of expectations of the family in the host and home countries. Further, in agreement with literature on immigrant entrepreneurship, our cases too rely on family trust (e.g., Jones et al., 2012). However, our study specifically links family trust to the forming of entrepreneurial ideas. Finally, in line with immigrant entrepreneurship literature (e.g., Ram et al., 2008), our study also shows that family support is important as a source of family social capital to exploit entrepreneurial ideas in the host and home countries by relying on families for getting new contacts which are useful in shaping entrepreneurial ideas.

Our article contributes to entrepreneurship in general and to immigrant entrepreneurship in particular as it offers an explanation about why families matter in the contemporary immigration process and in self-employment career choices. While social capital is nurtured in the (new) host country in the form of ethnic or non-ethnic peer relations, family social capital is the first natural choice of support for immigrant entrepreneurs in the process of creating entrepreneurial opportunities in both the host and home countries.

Our study has several implications for practitioners. It is important to understand that a family plays a significant role in promoting an open environment for creating entrepreneurial opportunities. However, family duties need to be balanced to foster and 
not to hinder the creation of entrepreneurial opportunities. Immigrant entrepreneurs develop entrepreneurial opportunities in the (new) host country because they have family duties, family trust and family support in both the host and home countries.

The rest of the paper is organized as follows. After the introduction, we provide a background of entrepreneurial opportunities and a perspective on the processes of creating entrepreneurial opportunities (Section 2). Thereafter, we discuss family social capital (Section 3). We then present our research methodology (Section 4) and then discuss our findings in Section 5 where we also suggest a model on family social capital in immigrant entrepreneurs' processes of opportunity creation. Finally, in Section 6 we present our theoretical contributions, limitations, possible areas for future research and implications for practitioners.

\section{Entrepreneurial opportunity creation and immigrant entrepreneurship}

Two dominant perspectives on entrepreneurial opportunities can be found in literature -- the entrepreneurial opportunity discovery perspective and the entrepreneurial opportunity creation perspective (Alvarez \& Barney, 2007; Zahra, 2008; Randerson et al., 2016). Literature on the perspective of entrepreneurial opportunity discovery suggests that opportunities exist and are waiting to be found (Shane, 2012). Their existence is independent of an entrepreneur's actions (Shane \& Venkataraman, 2000). The process of an entrepreneurial opportunity discovery starts with the identification of an entrepreneurial idea in an industry or market (Shane, 2000; Davidsson, 2003; Alvarez \& Barney, 2007) which is treated as a starting point for developing a new venture (Vaghely \& Julien, 2010). Thus, an entrepreneurial opportunity has to do with an exploration of existing industries and markets (Sarasvathy, Dew, Velamuri \& Venkataraman, 2003).

Literature on immigrant entrepreneurship commonly studies entrepreneurial opportunities using the discovery perspective. It addresses immigrant entrepreneurs' entrepreneurial opportunities as opportunity recognition and exploitation (Bolivar-Cruz, Batista-Canino \& Hormiga, 2014). Opportunity identification has been discussed, for example, by Dana (1995), Clydesdale (2008) and Smans, Freeman \& Thomas (2014) and opportunity discovery by, for example, Aliaga-Isla \& Rialp (2012). Literature also discusses opportunity structure (e.g., Tsui-Auch, 2005; and Vissak \& Zhang, 2014). In this literature, the process of discovering entrepreneurial opportunities is studied as a pre-venture process. This indicates that once a venture is launched the process of 
entrepreneurial opportunity creation comes to an end (e.g., De Koning \& Muzyka, 1999; Kloosterman, Van Der Leun \& Rath, 1999).

In contrast, the perspective of opportunity creation proposes that an entrepreneurial opportunity does not exist out there waiting to be discovered; instead, it exists once the creation process unfolds (Aldrich \& Waldinger, 1990; Alvarez \& Barney, 2007, 2013; Dimov, 2007a; Vogel, 2016). This perspective focuses on understanding how entrepreneurial ideas are generated and shaped (Gartner, Bird, \& Starr, 1992; Gartner, Carter \& Hills, 2003; Dimov, 2007a, 2007b) through a process in which entrepreneurs interact with their social context (e.g., Jack \& Anderson, 2002; Fletcher, 2006; Korsgaard \& Anderson, 2011). Entrepreneurial opportunities are seen as an active construction of circumstances and a form of world making (Sarasvathy, 2008; Korsgaard 2011, Vogel, 2016).

Thus, the process of opportunity creation occurs in a non-linear manner and consists of entrepreneurs' actions and reactions towards the context in an iterative manner (Alvarez \& Barney, 2007; Dimov, 2007a). It is based on a trial and error model (Vaghely \& Julien, 2010). Entrepreneurial opportunities are treated as on-going creation processes of: (1) forming an idea, and (2) exploiting the idea that takes place along the life of a business (e.g., Ardichvili, Cardozo \& Ray, 2003; Davidsson, 2003; Dimov, 2007a; Elo \& Volovelsky, 2016; Evansluong, 2016). The forming of an entrepreneurial idea denotes that an entrepreneur generates and shapes an idea by explaining it to different stakeholders in her or his immediate social network (Dimov, 2007a, 2011). The exploitation of an entrepreneurial idea involves the continuous refinement of the idea through interaction with customers and other stakeholders after the venture is created (Evansluong, 2016). According to this literature, the process of opportunity creation does not end when an entrepreneur launches a venture; instead, the process of opportunity creation continues as long as an entrepreneur works on the idea.

Our article adopts the perspective of opportunity creation since there are very few studies that use this perspective. In addition, our study will also increase our knowledge about the role of family in this particular context of immigrant entrepreneurship.

Literature on immigrant entrepreneurship focuses on three types of process models for studying entrepreneurial opportunities: static, stage and dynamic (e.g., Dana, 1995; Vinogradov \& Elam, 2010; Aliaga-Isla \& Rialp, 2012). In this literature, the family dimension is generally absent. The static process model focuses on identifying different factors linked to the host and home countries that influence the creation of an 
entrepreneurial opportunity at a specific point in time. For instance, Johnson, Muñoz \& Alon (2007) identify factors from the host country environment (entrepreneurial opportunities, institutional support) and the home country (motivation for emigration) that influence entrepreneurial activities carried out by Filipino entrepreneurs in the US. The authors suggest that immigrant entrepreneurs are most likely to start ventures when they have a tradition of family businesses. The family's influence is thus only present before the start of a venture. However, the model fails to illustrate the sequence of immigrant entrepreneurs' activities in the formation and exploitation of entrepreneurial ideas and how these activities are linked to the family dimension.

The stage model depicts the sequence of an immigrant entrepreneur's activities in forming and exploiting an entrepreneurial idea. For instance, Muzychenko (2008) proposes a model that combines competencies in identifying opportunities and entrepreneurial self-efficacy developed in the home country with cross-cultural competencies for identifying international opportunities in the host country. Using both these competencies results in the successful launch of international opportunities in the host country. However, what is noteworthy is that the family dimension is missing both as a source of competencies in identifying opportunities in the home country and also as a source of cross-cultural competencies in the host country. This model also fails to show how immigrant entrepreneurs interact with their families to develop competencies.

The dynamic model shows the relationships between different actors and the temporal sequence of actions. For instance, Elo \& Volovelsky (2016) studied six Jewish entrepreneurs to understand the influence of religion in exploring and exploiting entrepreneurial opportunities in the host country. The authors show that social capital provided entrepreneurs with information, connections and consultations. However, the authors do not consider the influence of family ties available in the diaspora during the process of creating opportunities.

Studying Australian SMEs, Chandra (2017) proposes a time-process model that shows that entrepreneurs employ simple to complex rules to evaluate international entrepreneurial opportunities. While this model distinguishes three processes in developing entrepreneurial opportunities (opportunity actualization, opportunity revision and opportunity maximization), it fails to show how entrepreneurs utilize personal resources like the family. The model also fails to show how an entrepreneur interacts with her or his family when applying the proposed rules to evaluate an entrepreneurial opportunity. 
This discussion shows that there are limited studies which investigate the influence of family in the host and home countries in the process of immigrant entrepreneurs' creating entrepreneurial opportunities. This is in line with Drori et al.'s (2009) research call to explore how immigrant entrepreneurs craft entrepreneurial opportunities by utilizing particular resources in more than one country. Hence, to gain more knowledge about the process of opportunity creation, it is important to gain a better understanding of specific influences such as the family dimension in the host and/or home country in the process of creating opportunities.

\section{Family social capital and opportunity creation}

Family social capital is one of the most acknowledged non-economic capital for developing immigrant businesses (Sanders \& Nee, 1996; Nee \& Sanders, 2001). While literature on immigrant entrepreneurship uses social capital extensively even though the family is pervasive in immigrant businesses, the perspective of family social capital has not been used in examining the family's influence in the host and home countries in the process of creating opportunities.

Social capital and family social capital are different. Social capital constitutes a 'resource for action' (Coleman, 1988: 95). It refers to the relations, networks and norms of reciprocity that an individual or an organization has with the overall environment (Nahapiet \& Ghoshal, 1998). In contrast, family social capital specifically recognizes the influence of the family on individuals, relations, ventures and related family businesses (Hoffman, Hoelscher \& Sorenson, 2006; Arregle, Hitt, Sirmon \& Very, 2007). The family provides a foundation of moral behaviour which guides cooperation, coordination and reciprocity (Arregle et al., 2007).

A close reading of literature on immigrant businesses shows that an immigrant entrepreneur relies on the social capital of her or his family and often also on the family business in the host and/or home country (e.g., Light \& Gold, 2000; Wong \& Ng, 2002; Bagwell, 2008; Dei Ottati, 2014). In this literature, a family is acknowledged as a social institution in which all entrepreneurial actions and processes are embedded (Aldrich \& Cliff, 2003; Jones \& Ram, 2007). By definition, embeddedness implies being part of a larger structure (Uzzi, 1997; Kloosterman et al., 1999). Individuals like immigrant entrepreneurs have relationships and networks which affect their social and economic actions (Granovetter, 1985; Portes \& Sensenbrenner, 1993; Nee \& Sanders, 2001). 
For the first generation of immigrants self-employment represents one of the primary means of social and economic mobility (Portes \& Zhou, 1992; Waldinger \& Lichter, 2003; Vinogradov \& Kolvereid, 2007). This was, for instance, the case of Korean and Taiwanese immigrants in the US (Nee \& Sanders, 2001). At the beginning of their move to the host country, their relations started with the closest ties, namely family, since they lacked social capital (that is, ethnic and non-ethnic ties in the host country). Immigrant entrepreneurs invested more in social capital relations within the family as an unintended consequence of their family concerns and interests (Nee \& Sanders, 2001).

The family was thus a repository of trust to interact with the larger social structure (Aldrich \& Waldinger, 1990). The trust generated in the family enabled individuals to make sacrifices of individual interests for the benefit of the group (Portes \& Sensenbrenner, 1993; Lo \& Teixeira, 2015). However, we know little about how trust influences the process of creating opportunities.

Literature on immigrant entrepreneurship provides a fragmented view of the role of the family in the formation and exploitation of an entrepreneurial idea. In the process of forming entrepreneurial ideas, immigrants are embedded in family relations in the host and home countries (Ram et al., 2008). For instance, in the case of Vietnamese nail-care services in the UK, immigrant entrepreneurs reported the importance of support from family members for start-ups in the host country (Bagwell, 2008). This support included learning the trade and getting help to export the business to the UK. There is, however, lack of discussion on the involvement of the family in developing entrepreneurial ideas. While some individuals migrate with their families (for example, Koreans and Taiwanese in the US) (Nee \& Sander, 2001), some immigrant entrepreneurs have families with members from different nationalities living outside their home countries.

Further, many immigrants fall in love with persons from the same nationality and settle down in a third country. Thus, immigrant entrepreneurs maintain and build relationships and networks with their family in the host and home countries (e.g., Rusinovic, 2008; Bagwell, 2008, 2015). Overall, this dynamics makes the role of the family in the process of forming entrepreneurial ideas complex.

In the process of exploiting entrepreneurial ideas, the family also plays an important role in resource mobilization (Yazdanfar \& Abbasian, 2013). Literature recognizes the presence of the family linked to existing businesses. For instance, in a study of Chinese, Korean and Filipino immigrants in the US, it was seen that the family provided labour for immigrants' ventures (Sanders \& Nee, 1996). In a case study of 
Somali immigrant entrepreneurs, family members accepted lower salaries and did voluntary work (Sanders \& Nee, 1996; Ram et al., 2008). Several studies also maintain that families provide financial support to immigrants for launching ventures (e.g., Sanders \& Nee, 1996; Bates, 1997; Yazdanfar \& Abbasian, 2013). This financial support is given as interest-free loans, low-interest loans or gifts to immigrant entrepreneurs (e.g., Ram et al., 2008; Jones et al., 2010; Aldén \& Hammarstedt, 2016). While research shows the influence and importance of family in running an existing business, there is lack of knowledge on the role of the family in exploiting an entrepreneurial idea.

In literature on family social capital, the family is an important source of non-economic capital (Danes, Stafford, Haynes \& Marapurkar, 2009). Portes and Sensenbrenner (1993) link immigrant socioeconomic activities to four sources of social capital that are relevant for entrepreneurship -- value introjection, reciprocity transactions, bounded solidarity and enforceable trust. Within family social capital, Sorenson, Goodpaster, Hedberg \& Yu (2009) find that the presence of ethical norms helped in cultivating family social capital for family businesses in the US; this was useful for developing businesses. Overall, the sources of family social capital generate expectations about an individual's specific behaviour because of the norms of reciprocity (Portes \& Sensenbrenner, 1993). They also build a broad base to examine the contribution of the family dimension in the entrepreneurial opportunity creation process.

We argue that the sources of family social capital available to immigrant entrepreneurs can help us to examine the role of the family in the host and home countries in the process of creating opportunities. Family social capital is guided by the values that immigrant entrepreneurs learned during the process of socialization (Berger \& Luckman, 1967). Thus, the specific resulting sources of family social capital become a resource for immigrant entrepreneurs; these are activated in the process of creating opportunities.

\section{Research methodology}

In agreement with recent calls for more research on the perspective of creating entrepreneurial opportunities (Dimov, 2011), we selected a qualitative method for our study.

Following Eisenhardt and Graebner (2007), we conducted an inductive case study to build a theory on the role of family social capital in the host and home countries in the 
process of creating entrepreneurial opportunities by immigrant entrepreneurs. Our study employed a process-oriented approach with a multiple case research design (Yin, 1994; Coviello \& Jones, 2004). In line with Dimov (2007a, 2011), opportunity creation was seen as a process by which (immigrant) entrepreneurs interacted with several stakeholders to develop their entrepreneurial ideas. Our unit of analysis was the process of opportunity creation where we examined the sources of family social capital as identified in our empirical study.

\subsection{Data collection}

The empirical setting selected for our case study rests on four cases of immigrant entrepreneurs from Lebanon, Syria, Cameroon and Mexico who started their businesses in Jönköping, Sweden (additional information on each case is presented in Table 1).

To minimize external variations beyond the phenomenon of interest (Eisenhardt, 1989), we selected four cases that were homogeneous under two theoretically relevant dimensions. First, the four cases are located in the same host country (Sweden) due to potential socioeconomic environmental issues affecting the entrepreneurial opportunity creation process. Sweden is a relevant context to study immigrant entrepreneurship since it is one of the countries that receives the largest number of immigrants in the world. The high unemployment rates among individuals with a foreign background are an increasing social and economic challenge for the Swedish labour market. As a result, many foreigners choose to start businesses. Second, the four cases are based in the same geographical region where immigrant entrepreneurship is pervasive (Jönköping). Jönköping is among the counties in Sweden which have the largest proportion of businesses owned by immigrant entrepreneurs (Swedish Agency for Economic and Regional Growth, 2013).

To strengthen the pattern recognition of the role of family in the entrepreneurial opportunity creation process, cases were carefully selected to represent what Pettigrew (1990) labels 'polar types' thus emphasizing a comparison between extreme differences under two theoretically relevant dimensions. First, we chose cases of ethnic groups that had the highest and lowest shares of self-employment in Sweden possibly due to financial and human capital issues affecting the process of creating entrepreneurial opportunities. We selected Lebanon and Syria in the Asian and Middle Eastern contexts because immigrants from these groups have the highest shares in Sweden, whereas Africans (Cameroon) and Latin Americans (Mexico) have the lowest shares in 
self-employment in Sweden (Swedish Agency for Economic and Regional Growth, 2013). We also chose cases from different industries and sectors with traditional and knowledge-intensive cases. Our cases include a restaurant, a beauty salon, a food retail shop and two IT software development service start-ups. We selected cases from different countries to account for cultural diversity in the home countries but because it also allowed us to identify similar patterns in the process of entrepreneurial opportunity creation. We selected cases from four different national cultural contexts including having spent varying time in Sweden and having family members in the host and home countries.

\section{PLEASE INSERT TABLE 1 ABOUT HERE}

The case studies were conducted between 2013 and 2016 in three phases (see Table 2). To understand the processes of creating opportunities and how the processes evolved through interactions with families, the case studies included interviews with the entrepreneurs, their family members and family friends as well as visits to their ventures. This paper is informed by 25 interviews with immigrant entrepreneurs and repeated visits conducted by the first author. At the time of the first interview, the author - a Vietnamese - had lived in Sweden for 10 years and had started a company. This background helped him build empathy with the interviewees. In Phase 1, the interviews included questions on entrepreneurs' motivations for starting the businesses, persons who were consulted to discuss the entrepreneurial ideas and help obtained from contacts living in the host and home countries. In Phase 2, the interviews considered changes made to the initial business ideas and how these changes happened, who or what influenced the changes and what were the main differences between the current business ideas and the original ideas. In Phase 3, the questions were aimed at understanding key influences of the family in the host and home countries. Interviews were recorded and transcribed verbatim.

\section{PLEASE INSERT TABLE 2 ABOUT HERE}

\subsection{Data analysis}

In line with Miles and Huberman (1984) and Eisenhardt (1989), the data analysis was organized in three steps: 
STEP 1. The authors read the material separately multiple times identifying the repeated presence of the family. Following an open coding procedure, different themes that re-occurred in the data were classified in an inductive manner in each case. This initial classification helped build several tables with excerpts from the transcripts of the interviews to search for cross-case patterns. The emerging themes were discussed to understand the underlying importance of the family's role and contribution in the process of creating opportunities.

STEP 2. The first author conducted four additional interviews in 2016 to examine the role of the family in the host and home countries in more detail. At this stage, both authors related the findings to literature on sources of family social capital to confirm patterns and allow comparisons of the findings with theory (Piekkari, Plakoyiannaki \& Welch, 2010). With these interviews, the authors also sought validation of their emerging findings. Immigrant entrepreneurs' families in the host and home countries played specific roles and contributed in different ways to the processes of creating opportunities. The data and tables were re-organized under three themes or sources of family social capital (Tables 4 to 6 ). The tables were linked to sources of family social capital as a foundation. These sources emerged from the empirical material.

STEP 3. Dana and Dumez (2015) propose a process of theory building that includes defining new concepts, defining the meanings of the new concepts and specifying an empirical field to which these concepts are applied. Thus, Table 3 illustrates the development from primary aspects (that is, specific meanings extracted from our data) to concepts (three sources of family capital) and three processes of opportunity creation (trigger process, formation process and exploitation process). An evaluation of the concepts led to the final step in which a model on family social capital in immigrant entrepreneurs' processes of opportunity creation was developed (Figure 1). The model represents the influence of the family in the process of creating opportunities by discussing the relationships between: (a) the concepts (that is, sources of family social capital), (b) the processes of opportunity creation, and (c) existing research on family social capital.

\section{Results}

Three sources of family social capital were identified -- family duty, family trust and family support. These were linked to three processes of opportunity creation: the trigger 
for an entrepreneurial idea, the formation of an entrepreneurial idea and the exploitation of an entrepreneurial idea. Our findings are summarized in Table 3 and indicate that based on the sources of family social capital, the family's influence in the process of opportunity creation varied.

\section{PLEASE INSERT TABLE 3 HERE}

Trigger process of an entrepreneurial idea - family duties

The first source, family duties, triggers the process of forming an entrepreneurial idea. This implies that immigrant entrepreneurs behave in responsible ways towards their families in the host and home countries because of two reasons. First, immigrant entrepreneurs take on the duties of being breadwinners for their nuclear families in the host country. Second, they also have pressure from their families in the host and home countries for being successful in the host country.

Immigrant entrepreneurs engage in developing entrepreneurial ideas to provide financial security to their nuclear families in the host country (Table 4 includes additional excerpts from our interviews). One immigrant entrepreneur in case 3 said:

In my case, I stopped being single. I got together with a Swedish girl. My son was born in 2008, therefore there were other expenses. I needed more money.

Immigrant entrepreneurs are also driven by a need to become successful in the host country by accomplishing economic upward mobility. When parents in the home country expect economic upward mobility from their children in the host country, immigrant entrepreneurs embrace entrepreneurial ideas as something that must be done successfully to financially support their families. In case 3, the immigrant entrepreneur stated:

In one way, yes, I think so (that I was supposed to do the same or more). They did not tell me that I needed to do it. This is something that I felt and I pushed it myself. I kept the responsibility of doing it, why? Because I think that it was a must, if my dad, my family had been working to give me the opportunity to be here and to do this, it's something that I had to do. 


\section{PLEASE INSERT TABLE 4 HERE}

Family duties originate in immigrant entrepreneurs' expectations of responsibilities towards their families in the host and home countries. Because of newly acquired responsibilities of a nuclear family in the (new) host country, an immigrant entrepreneur's family duties drive the entrepreneurial idea forward. A family duty of being successful implies that the extended family in the home country expects the upward mobility of an entrepreneur in the (new) host country (e.g., Chand \& Ghorbani, 2011; Dei Ottati, 2014). This pressure influences immigrant entrepreneurs to develop entrepreneurial ideas to provide better lives for their families. The expectations of responsibilities from families in the host and home countries depend on the specific positions of immigrant entrepreneurs in their societies in relation to class, gender and education. Thus, family duties can at times hinder the formation of an entrepreneurial idea since the financial pressure on an immigrant entrepreneur can become a burden. Based on this, the following proposition is developed:

Proposition 1: An immigrant entrepreneur's family duties in the host and home countries are more likely to trigger an entrepreneurial idea.

\section{Formation process of an entrepreneurial idea - family trust}

The second source of social capital, family trust, refers to the conviction and goodwill of the family in the host and home countries to support immigrant entrepreneurs in forming ideas. Family trust is shown through conversations with family members for developing an entrepreneurial idea in the host and home countries and in the family's willingness to help an entrepreneur when needed for developing an entrepreneurial idea in the host country. Immigrant entrepreneurs discussed entrepreneurial ideas extensively with their families in the host and home countries. One of the entrepreneurs in case 2 said:

My cousin, my sister and I, we met often. We discussed how the market looked for such products, the type of customers, how the customers needed the products.

Willingness to help means that family members in the host country were ready to help 
immigrants move forward from the formation of an entrepreneurial idea to its exploitation. The willingness to help started as emotional backing but developed into more concrete forms of conversations (Table 5 includes additional excerpts from our interviews). One of the entrepreneurs in case 3 said:

I realized that what we were doing was wrong because we were trying to start a company based on our thinking that it would be a consultancy but we had different things ... my parents told us, well, wake up, this is not a consultancy. This is a service and a product and it can be managed as a type of franchise. You should have a model on how to run that type of business, how you must calculate your prices and how you should promote your services.

\section{PLEASE INSERT TABLE 5 HERE}

Family trust creates an environment which permits responsive conversations for exchanging points of view and information that is useful for crafting an entrepreneurial idea. Previous research indicates that trust provides a foundation for entrepreneurial development (Deakins, Smallbone, Whittam \& Wyper, 2007) and that immigrants appreciate the trust of family members and also confirm the central importance of family members in their businesses (Lo \& Teixeira, 2015). In our cases, families of immigrant entrepreneurs in the host and home countries were prepared and available to discuss entrepreneurial ideas as and when needed. Family trust thus includes stronger ties among family members which lead to an open environment for shaping entrepreneurial ideas. Based on this, the following proposition is formulated:

Proposition 2: The greater an immigrant entrepreneur's family trust in the host and home countries, the greater the use of family conversations to advance an entrepreneurial idea.

Exploitation process of an entrepreneurial idea-family support

The third source of capital, family support, refers to the mobilization of family resources by an immigrant entrepreneur for exploiting an entrepreneurial idea. Family support means obtaining help in diverse areas from the family in the host and/or home 
country to exploit an entrepreneurial idea and obtain new contacts from the family in the host and/or home country for exploiting the entrepreneurial idea. The family in the host and home countries links immigrant entrepreneurs and their emerging ventures with their own businesses and other relevant business contacts (Table 6 includes additional excerpts from our interviews). One immigrant entrepreneur in case 3 said:

I think we were quite lucky to have a family that owned businesses... I think it's a big difference, than for example, those having restaurants as those have completely different models. My parents have experience in the governmental sector and in the private sector that helped us a lot in starting a company. When we finished university, we studied engineering so we had no knowledge about the business part when we started developing our business. We were a little too confident... I had been living in a business family for a while so... what happened in reality (was different) so we started asking them (about how to develop a business idea).

Immigrants obtain new contacts through their family members in the host and home countries that provide resources which are useful for exploiting entrepreneurial ideas. In our cases, this included relying on the family as an unpaid workforce, recruiting family members and acquiring knowledge from family and non-family businesses. One immigrant entrepreneur in case 1 said:

We went to Stockholm to visit my cousins and then we checked out kitchens in Lebanese restaurants to see how my Lebanese friends ran their restaurants. I wanted to check their menus to plan ours. My cousins introduced me to these friends.

\section{PLEASE INSERT TABLE 6 HERE}

Immigrant entrepreneurs have diverse family support available when it comes to exploiting entrepreneurial ideas; immigrant entrepreneurs benefit by accessing and obtaining their families' resources from the home-host country realm. These resources are provided for free or at a lower cost. Previous literature calls these resources 'ethnic resources' (Miera, 2008: 754). These include an unpaid/cheaper labour force, contacts, consultation and knowledge transfer (e.g. Sanders \& Nee, 1996; Bates, 1997; Yazdanfar 
\& Abbasian, 2013). The availability of these resources depends on the specific positions of immigrant entrepreneurs in their society in relation to class, gender and professional networks. Based on this, the following proposition is proposed:

Proposition 3: The greater an immigrant entrepreneur's family support in the host and home countries, the greater the access to free or lower cost family resources.

To sum up, our findings suggest that the influence of family in the home and/or the host country on the process of creating opportunities is prevalent and recurrent. Nonetheless, the influence differs as the processes of creating opportunities evolve. When we relate the sources of family social capital to the processes of creating opportunities, the family has specific roles. Figure 1 gives our model linking family social capital and the process of opportunity creation. Immigrant entrepreneurs navigate between the processes of creating opportunities by activating family engagement. By engaging the family in the host and home countries, entrepreneurs create a space in the host-home country realm for trying out, refining and improving entrepreneurial ideas.

\section{PLEASE INSERT FIGURE 1 HERE}

\section{Conclusions}

This paper's aim was to conduct an inductive case study to build a theory on the family's role in the host and home countries in immigrant entrepreneurs' creating entrepreneurial opportunities. Our research highlights that we can understand the role of the family in the host and home countries better by identifying the sources of family social capital in the processes of opportunity creation by immigrant entrepreneurs. While previous literature recognizes the significance of family in immigrants' ventures (Sanders \& Nee, 1996; Ram et al., 2008), our paper shows that three different sources -- family duty, family trust and family support -- enable the processes of opportunity creation by immigrant entrepreneurs. These sources lead to positive behaviours and expectations of immigrant entrepreneurs and their families because of the norms of reciprocity and solidarity. The family is present in the process of creating opportunities to support immigrant entrepreneurs' integration in a new society.

We now discuss the theoretical contributions of our research findings for literature on 
opportunity creation by immigrant entrepreneurs and entrepreneurs' family social capital.

\subsection{Theoretical Contributions}

Our study contributes to research on opportunity creation by immigrant entrepreneurs in three ways. First, our paper extends the research call for why, how and when do immigrant entrepreneurs pursue new business ventures (Drori et al., 2009) by adding the specific importance of the family dimension in explaining such a phenomenon. Dimov (2007a) emphasizes the importance of shaping entrepreneurial ideas through interacting with the immediate social network - family. However, his study does not portray how families shape entrepreneurial ideas. Previous literature on the process of opportunity creation pays limited attention to the family's influence (see an exception in Aldrich \& Cliff, 2003). As compared to Aldrich and Cliff (2003), Vaghely and Julien (2010), Dimov (2007a, 2011) and Zhara (2008), our study empirically demonstrates the roles that a family in the host and home countries plays in the processes of creating entrepreneurial ideas. These roles (duties, trust and support) show the multi-layered nature of the family dimension since it is linked to different processes of opportunity creation. The roles operate as a response to changing circumstances in the process of creating opportunities. In our cases, the existence of family duties, trust and support helped in developing successful entrepreneurial ideas.

The family acts as a repository of emotional, social and cognitive support stimulating entrepreneurial action in a new context (the host country). Families understand that entrepreneurs are in a new foreign context and they are not left alone.

Second, our paper answers the need for furthering our understanding about how the family and business are inter-related and how family dynamics affect the entrepreneurial process, especially the process of creating opportunities (Aldrich \& Cliff, 2003). The results of our study show that immigrants create entrepreneurial opportunities by making use of their family social capital in different ways. Available family social capital for immigrant entrepreneurs varies depending on the family's background and position in society. Prior literature recognizes family support for start-ups and in the running of businesses (Ram et al., 2008, Jones et al., 2012). While literature on immigrant entrepreneurship recognizes the family duties that entrepreneurs need to fulfil (e.g., Nee and Sanders, 2001), our study shows that the family matters even before an entrepreneurial idea is formed. Family duties have significant importance in generating business ideas. 
Third, our study extends Sanders and Nee's (1996) and Nee and Sanders' (2001) work on the perspective of family social capital by illustrating that the sources of family social capital change along the process of opportunity creation. We show that family dynamics influence the process of opportunity creation by means of family duties, family trust and family support. When looking through the lenses of these sources, the generated behaviours and expectations of the family differ in the trigger process, in forming an entrepreneurial idea and in exploiting an entrepreneurial idea. During opportunity creation, different resources are needed which are provided by the family for free or at a lower cost. The resources available to immigrant entrepreneurs are dependent in the context of opportunity creation in the host-home country space. Being an immigrant entrepreneur in a host country but remaining connected to the home country allows an entrepreneur to create a flexible space between these two countries. Such a space is activated by engaging the family when needed.

\subsection{Limitations and future research}

Despite its contributions to the process of creating entrepreneurial opportunities, our study has three limitations. First, since this paper is theory-building research, the cases selected for the study included four different cultural contexts (Lebanon, Syria, Cameroon and Mexico). Earlier research has shown that opportunity seeking behaviour differs according to the national background (Dana, 1995). Thus, future research needs to consider cases with similar host and home country backgrounds. This design will permit an examination of the specific aspects of a given ethnical group (that is, values, religion, traditions) that influence the process of creating opportunities. Such a design will also allow insights into the effect of culture on different ethnical groups in specific host countries.

Second, this paper does not specifically examine family relations and how immigrant entrepreneurs rely on them during the process of creating opportunities. Future research can look at the impact of the diversity of family relations on the processes of opportunity creation. Family relations can include interactions between spouses, parents and children, siblings and/or relatives. These relations have access to different bundles of resources and consequently their influence can vary in the process of opportunity creation.

Third, this paper relies on case studies of immigrant entrepreneurs from emerging economies and developing countries located in a developed country. There is lack of 
contextual research on opportunity creation by immigrant entrepreneurs forming and exploiting ideas in emerging economies and developing countries. Entrepreneurship and immigrant entrepreneurship in emerging economies and developing countries face dramatic circumstances and lack resources for pursuing opportunities (Ramírez Pasillas, Brundin \& Markowska, 2017). However, there is lack of research on the phenomena of immigrant entrepreneurship in these contexts. Also, there is lack of research on immigrant entrepreneurs from developed countries generating entrepreneurial ideas in developed or developing countries. A comparison of the processes of opportunity creation and family social capital in different contexts can further our understanding of the relevance and significance of the family, motivation and the types of businesses created.

\subsection{Implications for practitioners}

The results of our study have several implications for practitioners. Immigrant entrepreneurs, who seek to develop their ventures can rely on their family members as discussants of entrepreneurial ideas. They can leverage support from family members whenever appropriate. Relying on the family is a way of using family social capital for forming and exploiting entrepreneurial ideas. Policymakers, who want to develop business support for immigrant entrepreneurs can focus on systematic ways of helping immigrants map relevant family resources from their networks in the host and home countries. This mapping will facilitate the formation and exploitation of entrepreneurial ideas.

\section{Acknowledgements}

The authors wish to thank Dr Maria Elo and Dr Rodrigo Basco for their valuable feedback and suggestions on earlier versions of the paper. The authors also wish to recognize the helpful comments of anonymous reviewers on an earlier version of the paper. 


\section{References}

Aldén, L., \& Hammarstedt, M. (2016). Discrimination in the Credit Market? Access to Financial Capital among Self-employed Immigrants. Kyklos, Vol. 69, No. 1, 3-31.

Aldrich, H. E., \& Cliff, J. E. (2003). The pervasive effects of family on entrepreneurship: Toward a family embeddedness perspective. Journal of Business Venturing, Vol. 18, No. 5, 573-596.

Aliaga-Isla, R., \& Rialp, A. (2012). How do information and experience play a role in the discovery of entrepreneurial opportunities? The case of Latin-American immigrants in Barcelona. Latin American Business Review, Vol. 13, No. 1, 59-80.

Aldrich, H. E., \& Waldinger, R. (1990). Ethnicity and entrepreneurship. Annual Review of Sociology, Vol. 16, 111-135.

Alvarez, S. A., \& Barney, J. B. (2007). Discovery and creation: Alternative theories of entrepreneurial action. Strategic entrepreneurship journal, Vol. 1, No. 1-2, $11-26$.

Alvarez, S.A., \& Barney, J.B. (2010). Entrepreneurship and epistemology: the philosophical underpinnings of the study of entrepreneurial opportunities. Academy of Management Annals, Vol. 4, No.1, 557-583.

Alvarez, S. A., \& Barney, J. B. (2013). Epistemology, opportunities, and entrepreneurship: Comments on Venkataraman et al. (2012) and Shane (2012). Academy of Management Review, 38(1), 154-157.

Ardichvili, A., Cardozo, R., \& Ray, S. (2003). A theory of entrepreneurial opportunity identification and development. Journal of Business Venturing Vol. 1, No. 1, $105-123$.

Arregle, J.L., Hitt, M. A., Sirmon, D. G., \& Very, P. (2007). The Development of Organizational Social Capital: Attributes of Family Firms. Journal of Management Studies, Vol. 44, No. 1, 73-95.

Bagwell, S. (2008). Transnational family networks and ethnic minority business development: The case of Vietnamese nail-shops in the UK. International Journal of Entrepreneurial Behavior \& Research, Vol. 14, No. 6, 377-394.

Bagwell, S. (2015). Transnational entrepreneurship amongst Vietnamese businesses in London. Journal of Ethnic and Migration Studies, Vol. 41, No. 2, 329-349.

Bates, T. (1997). Financing small business creation: The case of Chinese and Korean immigrant entrepreneurs. Journal of Business Venturing, Vol. 12, No. 2, 109-124.

Berger, P., \& Luckman, T. (1967). The Social Construction of Reality. Harmondsworth, UK: Penguin Books.

Bolívar-Cruz, A., Batista-Canino, R. M., \& Hormiga, E. (2014). Differences in the perception and exploitation of entrepreneurial opportunities by immigrants. Journal of Business Venturing Insights, Vol. 1, 31-36.

Chand, M., \& Ghorbani, M. (2011). National culture, networks and ethnic entrepreneurship: A comparison of the Indian and Chinese immigrants in the US. International Business Review, 20(6), 593-606.

Chandra A. (2017). time-based process model of international entrepreneurial opportunity evaluation. Journal of International Business Studies, 1-29.

Clydesdale, G. (2008). Business immigrants and the entrepreneurial nexus. Journal of International Entrepreneurship, Vol. 6, No. 3, 123-142. 
Coleman, J.S. (1988). Social capital in the creation of human capital. American Journal of Sociology, Vol. 94, 95-120.

Coviello, N. E., \& Jones, M. V. (2004). Methodological issues in international entrepreneurship research. Journal of Business Venturing, Vol. 19, No. 4, 485-508.

Dana, L.P. (1995). Entrepreneurship in a remote Sub-Artic community. Entrepreneurship Theory and practice, Vol. 20, No. 1, 55-72.

Dana, L.P. \& Dumez, H. (2015). Qualitative research revisited: epistemology of a comprehensive approach. International Journal Entrepreneurship and Small Business, Vol. 26, No. 2, 154-169.

Danes, S. M., Stafford, K., Haynes, G., \& Amarapurkar, S. S. (2009). Family capital of family firms: Bridging human, social, and financial capital. Family Business Review, Vol. 22, No. 3,199-215.

Davidsson, P. (2003). The domain of entrepreneurship research: Some suggestions. Advances in Entrepreneurship, Firm Emergence and Growth, Vol. 6, No. 3, 315-372.

De Koning, A. J., \& Muzyka, D. F. (1999). Conceptualising opportunity recognition as a socio-cognitive process. Stockholm: Centre for advanced studies in leadership.

Deakins, D., Ishaq, M., Smallbone, D., Whittam, G., \& Wyper, J. (2007). Ethnic minority businesses in Scotland and the role of social capital. International Small Business Journal, Vol. 25, No. 3, 307-326.

Dei Ottati, G. (2014). A transnational fast fashion industrial district: an analysis of the Chinese businesses in Prato. Cambridge Journal of Economics, Vol. 38, No. 5, 1247-1274.

Dimov, D. (2007a). Beyond the single-person, single-insight attribution in understanding entrepreneurial opportunities. Entrepreneurship Theory and Practice, Vol. 31, No. 5, 713-731.

Dimov, D. (2007b). From opportunity insight to opportunity intention: The importance of person-situation learning match. Entrepreneurship Theory and Practice, Vol. 31, No. 4, 561-583.

Dimov, D. (2011). Grappling with the unbearable elusiveness of entrepreneurial opportunities. Entrepreneurship Theory and Practice, Vol. 35, No. 1, 57-81.

Drori, I., Honig, B., \& Wright, M. (2009). Transnational entrepreneurship: An emerging field of study. Entrepreneurship Theory \& Practice, Vol. 33, No. 5, 1001-1022.

Eisenhardt, K.M. (1989). Building theories from case study research. Academy of Management Review, Vol. 14, No. 4, 530-550.

Eisenhardt, K. M., \& Graebner, M. E. (2007). Theory building from cases: Opportunities and challenges. Academy of Management Journal, Vol. 50, No. 1, 25-32.

Elo, M., \& Volovelsky Katz, E. (2016) Jewish diaspora entrepreneurs - the impact of religion on opportunity exploration and exploitation. International Journal of Entrepreneurship and Small Business. [In Press].

Evansluong, Q. (2016). Opportunity creation as a mixed embedding process: A study of immigrant entrepreneurs in Sweden(Doctoral dissertation), Jönköping University, Jönköping International Business School.

Fletcher, D. F. (2006). Entrepreneurial processes and the social construction of opportunity. Entrepreneurship and Regional Development, Vol. 18, No. 5, 421-440.

Gartner, W.B, Bird, B.J., \& Starr, J.A. (1992). Acting as if: Differentiating entrepreneurial from organizational behavior. Entrepreneurship Theory and Practice, Vol. 17, No. 3, 13-31. 
Gartner, W. B., Carter, N. M., \& Hills, G. E. (2003). "The language of opportunity". In C. Steyaert \& Hjort, D. (eds.), New Movements in Entrepreneurship. Cheltenham, UK: Edward Elgar.

Granovetter, M. (1985). Economic action and social structure: The problem of embeddedness. American Journal of Sociology, 481-510.

Hills, G. E., Lumpkin, G. T., \& Singh, R. P. (1997). Opportunity recognition: Perceptions and behaviors of entrepreneurs. Frontiers of entrepreneurship research, Vol. 17, 168-182.

Hoffman, J., Hoelscher, M., \& Sorenson, R. (2006). Achieving Sustained Competitive Advantage: A Family Capital Theory. Family Business Review, Vol. 19, No. 2, $135-145$.

Jack, S. L., \& Anderson, A. R. (2002). The effects of embeddedness on the entrepreneurial process. Journal of Business Venturing, Vol. 17, No. 5, 467-487.

Jones, T., \& Ram, M. (2007). Re-embedding the ethnic business agenda. Work, Employment and Society, Vol. 21, No. 3, 439-457.

Jones, T., Ram, M., \& Theodorakopoulos, N. (2010). Transnationalism as a force for ethnic minority enterprise? The case of Somalis in Leicester. International Journal of Urban and Regional Research, Vol. 34, No. 3, 565-585.

Jones, T., Ram, M., Edwards, P., Kiselinchev, A., \& Muchenje, L. (2012). New migrant enterprise: novelty or historical continuity?. Urban Studies, Vol. 49, No. 14, 3159-3176.

Johnson, J. P., Muñoz, J. M., \& Alon, I. (2007). Filipino ethnic entrepreneurship: An integrated review and propositions. International Entrepreneurship and Management Journal, Vol. 3, No. 1, 69-85.

Kloosterman, R. (2010). Matching opportunities with resources: a framework for analyzing (migrant) entrepreneurship from a mixed embeddedness perspective. Entrepreneurship and Regional Development, Vol. 22, No. 1, 25-45.

Kloosterman, R., J. van Leun, \& Rath, J. (1999). Mixed Embeddedness: (In)Formal Activities and Immigrant Businesses in the Netherlands. International Journal of Urban and Regional Research, Vol. 23, No. 2, 252-266.

Korsgaard, S. (2011). Entrepreneurship as translation: Understanding entrepreneurial opportunities through actor-network theory. Entrepreneurship \& Regional. Development, Vol. 23, No. 7-8, 661-680.

Korsgaard, S., \& Anderson, A. R. (2011). Enacting entrepreneurship as social value creation. International Small Business Journal, Vol. 29, No. 2, 135-151.

Light, I., \& Gold, S. (2000). Ethnic economies. San Diego, CA: Academic Press.

Lo, L., \& Teixeira, C. (2015). Immigrants doing business in a mid-sized Canadian City: Challenges, opportunities, and local strategies in Kelowna, British Columbia. Growth and Change, Vol. 46, 631-653.

Miera, F. (2008). Transnational strategies of Polish migrant entrepreneurs in trade and small business in Berlin. Journal of Ethnic and Migration Studies, Vol. 34, No. 5, 753-770.

Miles, M.B., \& Huberman, A.M. (1984). Qualitative data analysis. Beverly Hills, CA: Sage.

Muzychenko, O. (2008). Cross-cultural entrepreneurial competence in identifying international business opportunities. European Management Journal, Vol. 26, No. 6, 366-377.

Nahapiet, J., \& Ghoshal, S. (1998). Social capital, intellectual capital, and the organizational advantage. Academy of Management Review, Vol. 23, No. 2, $242-266$. 
Nee, V. \& Sanders, J. (2001). Understanding the diversity of immigrant incorporation: a forms-of-capital model. Ethnic and Racial Studies, Vol. 24, No. 3, 386-411.

Pettigrew, A.M. (1990). Longitudinal field research on change. Theory and Practice. Organization Science, Vol. 1, 267-292.

Piekkari, R., Plakoyiannaki, E., \& Welch, C. (2010). 'Good' case research in industrial marketing: Insights from research practice. Industrial Marketing Management, Vol. 39, No. 1, 109-117.

Portes, A., \& Sensenbrenner, J. (1993). Embeddedness and immigration: Notes on the social determinants of economic action. American Journal of sociology, Vol. 98, No. 6, 1320-1350.

Portes, A., \& Zhou, M. (1992). Gaining the upper hand: economic mobility among immigrant and domestic minorities. Ethnic and Racial Studies, 15(4), 491-522.

Ram, M., \& Holliday, R. (1993). Relative merits: family culture and kinship in small firms. Sociology, Vol. 27, No. 4,629-648.

Ram, M., Theodorakopoulos, N., \& Jones, T. (2008). Forms of capital, mixed embeddedness and Somali enterprise. Work, Employment \& Society, Vol. 22, No. 3, 427-446.

Ramírez Pasillas, M., Brundin, E., \& Markowska, M., (eds) (2017) Contextualizing Entrepreneurship in Emerging Economies and Developing Countries. Edward Elgar.

Randerson, K., Degeorge, J.M., \& Fayolle, A. (2016). Entrepreneurial opportunities: how do cognitive styles and logics of action fit in? International Journal of Entrepreneurship and Small Business, Vol. 27, No., 1-21.

Rusinovic, K. (2008). Transnational embeddedness: Transnational activities and networks among first-and second-generation immigrant entrepreneurs in the Netherlands. Journal of Ethnic and Migration Studies, Vol. 34, No. 3, 431-451.

Sarasvathy, S.D. (2008). Effectuation: Elements of entrepreneurial expertise. Cheltenham: Edward Elgar.

Sarasvathy, S.D., Dew, N., Velamuri, R., \& Venkataraman, S. (2003). Three Views of Entrepreneurial Opportunity. In Zoltan J. Acs and Audretsch, D.B. (eds.), Handbook of Entrepreneurship Research, New York: Kluwer, 141-160.

Sanders, J. M., \& Nee, V. (1996). Immigrant self-employment: The family as social capital and the value of human capital. American Sociological Review, Vol. 52, 231-249.

Shane, S. (2000). Prior knowledge and the discovery of entrepreneurial opportunities. Organization Science, Vol. 11, No. 4, 448-469.

Shane, S. (2012) Reflection on the 2010 AMR decade award delivering on the promise of entrepreneurship as a field of research. Academy of Management Review, Vol. 37, No. 1, pp.10-20.

Shane, S., \& Venkataraman, S. (2000). The promise of entrepreneurship as a field of research. Academy of Management Review Vol. 25, No. 1, 217-226.

Smans, M., Freeman, S., \& Thomas, J. (2014). Immigrant entrepreneurs: The identification of foreign market opportunities. International Migration, Vol. 52, No. 4, 144-156.

Sorenson, R.L., Goodpaster, K.E., Hedberg, P.R., \& Yu, A. (2009). The family point of view family social capital, and firm performance: an exploratory test. Family Business Review, Vol. 22, No. 3, 239-253.

Suddaby, R., Bruton, G.D., \& Si, S.X. (2015). Entrepreneurship through a qualitative lens: Insights on the construction and/or discovery of entrepreneurial opportunity. Journal of Business Venturing, Vol. 30, No. 1, 1-10. 
Sweden Agency for Economic and Regional Growth (2013). Företagare med utländsk bakgrund. Entreprenörskapsbarometern, Stockholm: Danagårds Grafiska AB.

Tsui-Auch, L.S. (2005). Unpacking regional ethnicity and the strength of ties in shaping ethnic entrepreneurship. Organization Studies, Vol. 26, No. 8, 1189-1216.

Uzzi, B. (1997). Social structure and competition in interfirms networks: the paradox of embeddedness. Administrative Science Quarterly, Vol. 42, No. 1, 35-67.

Vaghely, I.P., \& Julien, P.A. (2010). Are opportunities recognized or constructed? An information perspective on entrepreneurial identification. Journal of Business Venturing, Vol. 25, No. 1, 73-86.

Vinogradov, E., \& Kolvereid, L. (2007). Cultural background, human capital and self-employment rates among immigrants in Norway. Entrepreneurship \& Regional Development, Vol. 19, No. 4, 359-376.

Vinogradov, E., \& Elam, A. (2010). A Process Model of Venture Creation by Immigrant Entrepreneurs. In Brush, C., Kolvereid, L. Widding, L.O. \& Sorheim, R. (eds) The Life Cycle of New Ventures: Emergence, Newness and Growth. Cheltenham, UK: Edward Elgar Publishing.

Vissak, T., \& Zhang, X. (2014). Chinese immigrant entrepreneurs' involvement in internationalization and innovation: Three Canadian cases. International Journal of Entrepreneurship and Small Business, Vol. 27, No., 1-21. 12:183-201

Vogel, P. (2016), From Venture Idea to Venture Opportunity. Entrepreneurship Theory and Practice. doi:10.1111/etap.12234Waldinger, R. D. \& Lichter, M. I. (2003). How the other half works: Immigration and the social organization of labor. Berkeley, CA: University of California Press.

Wong, L. L., \& Ng, M. (2002). The emergence of small transnational enterprise in Vancouver: The case of Chinese entrepreneur immigrants. International Journal of Urban and Regional Research, Vol. 26, No. 3, 508-530.

Yazdanfar, D., \& Abbasian, S. (2013). The determinants of informal capital in the financing of small firms at start-up: An ethnic comparison of small firms in Sweden. International Journal of Economics and Finance, Vol. 5, No. 3, 62-72.

Yin, R. K. 1994. Case study research: Design and methods (2nd ed.). Newbury Park, CA: Sage.

Zahra, S. A. (2008). The virtuous cycle of discovery and creation of entrepreneurial opportunities. Strategic Entrepreneurship Journal, Vol. 2, No. 3, 243-257. 
Table 1. Cases in the study

\begin{tabular}{|c|c|c|c|c|c|c|c|}
\hline Case & $\begin{array}{l}\text { Type of } \\
\text { business }\end{array}$ & $\begin{array}{l}\text { Year in } \\
\text { which } \\
\text { established }\end{array}$ & $\begin{array}{l}\text { Country of } \\
\text { origin }\end{array}$ & $\begin{array}{l}\text { Years } \\
\text { residing in } \\
\text { Sweden }\end{array}$ & Family & $\begin{array}{lll}\text { Formation } & \text { of } & \text { an } \\
\text { entrepreneurial idea }\end{array}$ & $\begin{array}{l}\text { Exploitation of an entrepreneurial } \\
\text { idea }\end{array}$ \\
\hline 1 & Restaurant & 2004 & $\begin{array}{l}\text { Lebanon and } \\
\text { Syria }\end{array}$ & $\begin{array}{l}\text { Entrepreneur } \\
1 \mathrm{a}, 36 \\
\text { Entrepreneur } \\
1 \mathrm{~b}, 41\end{array}$ & $\begin{array}{l}\text { Nuclear family in Sweden } \\
\text { Extended family in Sweden }\end{array}$ & A Lebanese restaurant & $\begin{array}{l}\text { A Lebanese restaurant in Jönköping } \\
\text { which offers Lebanese cuisine with } \\
\text { original Lebanese taste, belly dancing } \\
\text { and shisha }\end{array}$ \\
\hline 2 & $\begin{array}{ll}\text { Food, } & \text { hair } \\
\text { shop } & \text { and } \\
\text { saloon } & \end{array}$ & 2009 & Cameroon & $\begin{array}{l}\text { Entrepreneur } \\
2,13\end{array}$ & $\begin{array}{l}\text { Nuclear family in Sweden } \\
\text { Extended family in } \\
\text { Cameroon and Sweden }\end{array}$ & $\begin{array}{l}\text { A beauty salon with an } \\
\text { African touch } \\
\text { A food store } \\
\text { Beauty care products } \\
\text { Cargo business }\end{array}$ & $\begin{array}{l}\text { A combination of a beauty salon and } \\
\text { an African food store. Features: hair } \\
\text { care and skincare products and } \\
\text { African food for Africans in } \\
\text { Huskvarna. The food store is the } \\
\text { main service }\end{array}$ \\
\hline 3 & $\begin{array}{l}\text { IT software } \\
\text { development } \\
\text { and } \\
\text { hardware } \\
\text { maintenance }\end{array}$ & 2011 & Mexico & $\begin{array}{l}\text { Entrepreneur } \\
3 \mathrm{a}, 11 \\
\text { Entrepreneur } \\
3 \mathrm{~b}, 8\end{array}$ & $\begin{array}{l}\text { Nuclear family in Sweden } \\
\text { Extended family in Mexico }\end{array}$ & $\begin{array}{l}\text { Providing IT programming } \\
\text { services between Sweden } \\
\text { and Mexico through the } \\
\text { parents' business network in } \\
\text { Mexico and with a service } \\
\text { oriented mind-set in Mexico }\end{array}$ & $\begin{array}{l}\text { Software development to local } \\
\text { companies in Sweden with } \\
\text { personalized customer service }\end{array}$ \\
\hline 4 & $\begin{array}{l}\text { IT software } \\
\text { development }\end{array}$ & 2012 & Mexico & $\begin{array}{l}\text { Entrepreneur } \\
4 \mathrm{a}, 6 \\
\text { Entrepreneur } \\
4 \mathrm{~b}, 7\end{array}$ & $\begin{array}{l}\text { Extended family in Mexico } \\
\text { Nuclear family in Sweden }\end{array}$ & $\begin{array}{l}\text { High quality } \\
\text { services to } \\
\text { companies }\end{array}$ & $\begin{array}{l}\text { Providing IT software development } \\
\text { to companies in Sweden using an } \\
\text { outsourcing team in Mexico with } \\
\text { high quality, high efficiency and } \\
\text { creativity }\end{array}$ \\
\hline
\end{tabular}


Table 2. Phases of data collection

\begin{tabular}{|l|l|l|}
\hline Phase & Focus & $\begin{array}{l}\text { No. of } \\
\text { interviews }\end{array}$ \\
\hline Phase 1 & $\begin{array}{l}\text { Getting to know the immigrant entrepreneurs } \\
\text { and their entrepreneurial processes }\end{array}$ & 9 \\
\hline Phase 2 & $\begin{array}{l}\text { Examining the immigrant entrepreneurs' } \\
\text { processes of creating entrepreneurial } \\
\text { opportunities in the host and home countries }\end{array}$ & 12 \\
\hline Phase 3 & $\begin{array}{l}\text { Examining the immigrant entrepreneurs' family } \\
\text { influences in more detail }\end{array}$ & 4 \\
\hline & Total number of interviews & $\mathbf{2 5}$ \\
\hline
\end{tabular}


Table 3. Sources of family capital in the process of creating opportunities

\begin{tabular}{|c|c|c|c|}
\hline \multirow{2}{*}{$\begin{array}{l}\text { Sources of family } \\
\text { social capital }\end{array}$} & \multicolumn{3}{|c|}{ Opportunity creation } \\
\hline & Trigger process for an entrepreneurial idea & Forming an entrepreneurial idea & Exploiting an entrepreneurial idea \\
\hline $\begin{array}{l}\text { 1. Family } \\
\text { duty }\end{array}$ & $\begin{array}{l}\text { (1a) providing financial security to the nuclear family by } \\
\text { developing a feasible entrepreneurial idea in the host } \\
\text { country } \\
\text { (1b) parents expecting the upward economic mobility of } \\
\text { their children/immigrant entrepreneurs in the host country }\end{array}$ & & \\
\hline 2. Family trust & & $\begin{array}{l}\text { (2a) families in the host country and extended } \\
\text { families in the home country engaging in } \\
\text { conversations with immigrant entrepreneurs about } \\
\text { entrepreneurial ideas } \\
\text { (2b) the willingness of the nuclear family in the } \\
\text { host country and the extended family in the home } \\
\text { country to help an immigrant entrepreneur to } \\
\text { develop an entrepreneurial idea }\end{array}$ & \\
\hline 3. Family support & & & $\begin{array}{l}\text { (3a) obtaining support from immigrant } \\
\text { entrepreneurs' nuclear and extended families } \\
\text { in the host and/or home country to exploit } \\
\text { entrepreneurial ideas } \\
\text { (3b) obtaining new contacts from the } \\
\text { immigrant entrepreneurs nuclear and } \\
\text { extended families in the host and/or home } \\
\text { country to exploit entrepreneurial ideas }\end{array}$ \\
\hline
\end{tabular}


Table 4. Additional excerpts of interviews on family duties in the host and home countries

\begin{tabular}{|l|l|}
\hline Case & Excerpt \\
\cline { 2 - 2 } & $\begin{array}{l}\text { Entrepreneur la: Immigrants who come here work hard to have a better life } \\
\text { than what they had in their home countries. That is the reason why people } \\
\text { leave their home countries. } \\
\text { Entrepreneur la: My father was a priest. He encouraged us to study in the } \\
\text { university. However, we were keen on earning money and doing what we } \\
\text { could do for our home and family. }\end{array}$ \\
\hline $\begin{array}{l}\text { Entrepreneur 2: I was like, I have to do this (start a company and support my } \\
\text { family). I wanted to do it, I must do it, I would do it. I went to the local } \\
\text { newspaper. I told them that I wanted to work in the night (so that I could open } \\
\text { my business). I liked the job because it was at night. I had enough time during } \\
\text { the day to meet customers. }\end{array}$ \\
$\begin{array}{l}\text { Entrepreneur 3a: I guess the answer is that it depends on who you ask. } \\
\text { Because everybody expects something better for their kids. The question is } \\
\text { what is better for me and what is better for you? }\end{array}$ \\
$\begin{array}{l}\text { Entrepreneur } 3 b: \text { They (my parents) were our bosses but they were also our } \\
\text { parents so they realized that 'the children are not going to come back' so they } \\
\text { started pushing and said, 'you know, move forward, start the company, start } \\
\text { looking for customers.' Of course, we also responded in a positive way: 'Let's } \\
\text { go and find the companies here and do the same thing that we do in Mexico in } \\
\text { Sweden.' Then things started moving and that's how we started looking for } \\
\text { customers in Sweden. We got customers I think in 2011. } \\
\text { Entrepreneur 3b: Yes, well, I have a lot of pressure I would say. Because both } \\
\text { my parents are highly educated and they are involved in a lot of important } \\
\text { projects in Mexico. My mom has bachelor's degrees in mathematics, physics } \\
\text { and education. So, she is really highly educated. She's been developing } \\
\text { educational programmes at the basic, middle and high levels ... }\end{array}$ \\
\hline
\end{tabular}


Table 5. Excerpts of interviews on family trust in the host and home countries

\begin{tabular}{|l|l|}
\hline $\mathbf{1}$ & $\begin{array}{l}\text { Excerpts } \\
\text { Entrepreneur 1a: We often took a walk together and we discussed the idea of a } \\
\text { Lebanese restaurant in Jönköping, and we worked it out together. }\end{array}$ \\
$\begin{array}{l}\text { Entrepreneur 1: My wife works in a kindergarten. Even if something went } \\
\text { wrong (with the business that we were planning to establish), my wife and I } \\
\text { could manage. It was not a life and death (decision). Therefore, my family said } \\
\text { okay, go for it (the Lebanese restaurant). }\end{array}$ \\
\hline $\mathbf{2}$ & $\begin{array}{l}\text { Entrepreneur 2: I talked to Remi who is one of my best friends about it too } \\
\text { and she was so happy. I told her that I would make it happen. }\end{array}$ \\
$\begin{array}{l}\text { Entrepreneur 2: When my husband and I divorced, it was almost impossible to } \\
\text { replace him. I told my friends I was stuck. My husband had helped me but he } \\
\text { did not earn any salary. He was just helping me. If I had to hire somebody, I } \\
\text { would have to pay taxes. I would have to pay social welfare and all those } \\
\text { things and then it was going to be nothing (for me) from the business. }\end{array}$ \\
\hline $\mathbf{3}$ & $\begin{array}{l}\text { Entrepreneur } 3 a: \text { I guess we do not have someone here in Sweden to talk to in } \\
\text { the same way that I talk to my dad in Mexico... my dad basically told me: } \\
\text { 'you know what, in Mexico they are doing this in IT so why don't you } \\
\text { implement it?' Yes, that's definitely something. } \\
\text { Entrepreneur 3b: Our parents were the bosses, they were always like 'do this, } \\
\text { do that,' but we didn't realize that they were already giving us directions } \\
\text { because they had experience... then we started listening to our parents, our } \\
\text { authorities you know and at the end it's like, 'hey, listen, do this, no you don't } \\
\text { know everything, you have to realize where you are, how you are,' and that } \\
\text { process was the most complex for us to switch our minds to and say, 'what is } \\
\text { your business?' They (our parents) are professionals so listen to them and } \\
\text { research more, do your homework, do a marketing analysis and start reading } \\
\text { about how to start a business. } \\
\text { she had. } \\
\text { In some way, I had been waiting for it to happen. I said to my wife, we need to }\end{array}$ \\
\hline
\end{tabular}


Table 6. Excerpts of interviews on family support in the host and home countries

\begin{tabular}{|c|c|}
\hline Case & Excerpt \\
\hline 1 & $\begin{array}{l}\text { Entrepreneur 1: When I asked my family for help, I received help from them but it } \\
\text { was not as much as I had asked for. My wife sometimes came to the restaurant and } \\
\text { helped me. My partner's wife also helped us. They knew that the food we cooked (in } \\
\text { the restaurant) was like the food we cook at home. They helped us a little. } \\
\text { Entrepreneur } 1 \mathrm{~b} \text { :... The family prepared food for my restaurant. I mean my wife, my } \\
\text { partner's wife and his sisters. Everybody was involved because there was a lot to do. } \\
\text { So they went out and helped us with the food preparation because there were a lot of } \\
\text { things (to be done). }\end{array}$ \\
\hline 2 & $\begin{array}{l}\text { Entrepreneur 2: My husband was active in the business by helping with the shop. He } \\
\text { was always assisting customers. When I was not there or when I was at home with the } \\
\text { kids, or when I did other things, or when I was in the salon doing hair, he was the one } \\
\text { assisting customers. He also helped in the money section, in particular in the transfer } \\
\text { of money. He was the one at the counter. I did not employ any (other) person because } \\
\text { he was there. } \\
\text { Entrepreneur 2: It was like connecting people who travelled to Cameroon. For } \\
\text { example, a friend of Jerome, travels from Malmö to Cameroon. Jerome (step brother) } \\
\text { called me and informed me that he has a friend who travels to Cameroon and said, 'do } \\
\text { you want him to bring stuff?' It's cheaper to do it that way. If somebody travels from } \\
\text { Stockholm to Cameroon, my cousin informs me. I tell him to bring me some stuff. We } \\
\text { can pay for the extra luggage. }\end{array}$ \\
\hline 3 & $\begin{array}{l}\text { Entrepreneur 3a: Since I arrived in Sweden I had been working for my family } \\
\text { company in Mexico. In my family company, we do consultancy on business } \\
\text { processes. I didn't have anything to do with business....I was in charge of developing } \\
\text { software applications...then I started my own family and needed more money. So I } \\
\text { started a business while I kept on working in my family company. }\end{array}$ \\
\hline 4 & $\begin{array}{l}\text { Entrepreneur 4a: One of my uncles has a good accounting company. He knows } \\
\text { everything about taxes. He was able to give me advice in that area. } \\
\text { Entrepreneur 4a: Probably at the beginning when we were naming our company, we } \\
\text { asked our friends and family that if you hear this name, what comes to your mind? } \\
\text { (We also asked) our friends and family in Mexico. As we do business with our friends } \\
\text { they were really interested in the idea. }\end{array}$ \\
\hline
\end{tabular}


Figure 1. Family social capital in immigrant entrepreneurs' processes of opportunity creation

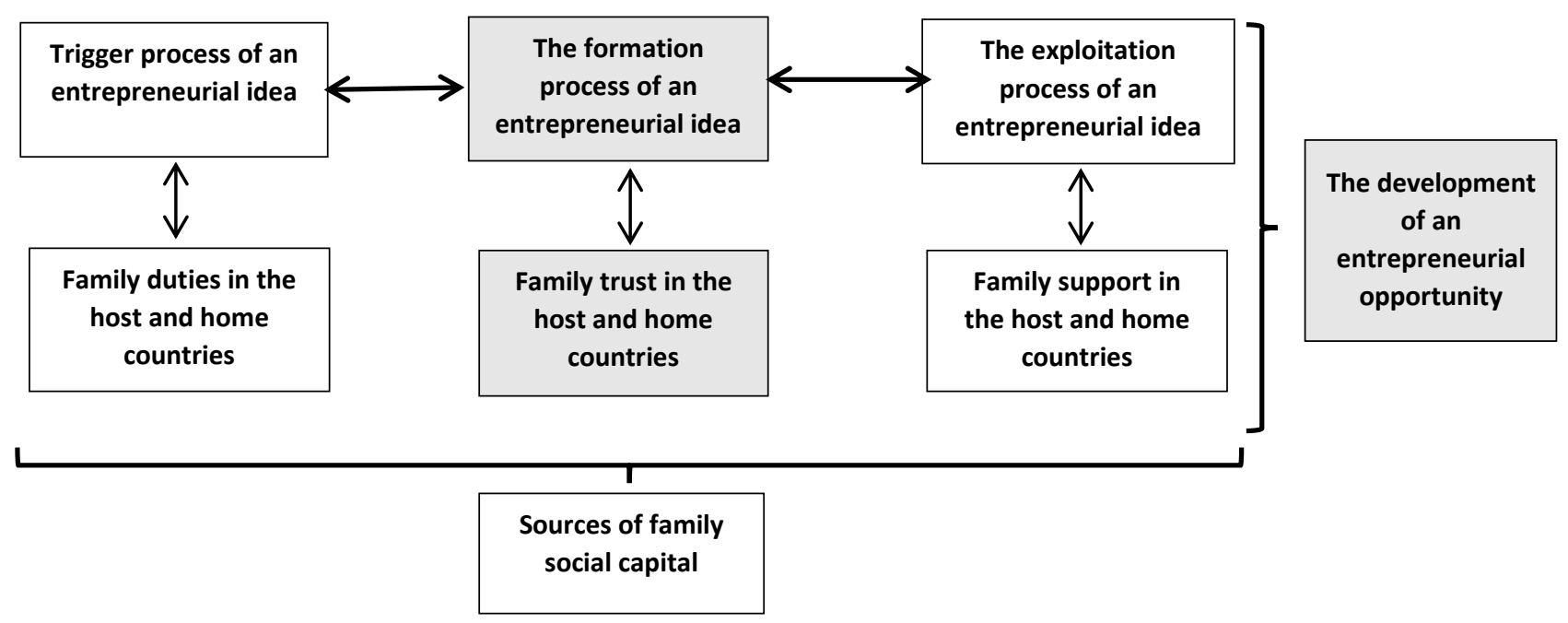

